\title{
Consumer Protection On So Called Discount Websites ${ }^{1}$
}

\author{
Blanka Vítová ${ }^{2}$
}

\section{Faculty of Law, Palacký University Olomouc, Czech Republic email: blanka.vitova@upol.cz}

VÍTOVÁ, B. Consumer Protection On So Called Discount Websites. International and Comparative Law Review, 2013, Vol. 13., No. 2, pp. 121-131. DOI: 10.1515/iclr-2016-0075.

\begin{abstract}
The subject of this article is the The "Deal-of-the-day" operators (discount website operators, such as Slevomat in the Czech Republic, or Groupon at the international level) and their practices, which can be unknown territory for most of their consumers. "Deal-of-the-day" websites (discount websites) are websites offering consumers a service to buy discounted (often gift) certificates (coupons or vouchers) which can be used at local or national companies. When examining the issue deeply, we realise that there are many potential threats for the consumers who are not as well protected by consumer law as they should be. The article covers these problematic areas.
\end{abstract}

Keywords: Deal-of-the-day, discount websites, consumer protection, discounted coupons.

\section{Introduction}

Consumer protection regulation is a specific area, which is influenced by the law of the European Union. Community legislation is a specific set of rules that is neither international law nor national law. It comprises the treaties, secondary law, and the case law of the Court of Justice of the European Union, which in its judgments offers a binding interpretation of Community law and, in certain cases, on this basis directly formulates the prescriptive provisions. The European Union's consumer legislation, on the other hand, is mainly composed of directives originally approved by the Council.

The regulation of consumer protection covers a number of different themes, which leads to its fragmentation. Separate provisions apply, for example, to the regulation of the composition and quality of products or services, consumer contracts (including, for example, doorstep selling or the conclusion of distance contracts), consumer credits, electronic commerce, etc.

One of the potential threats to consumers is the so called "Deal-of-the-day" operator services (discount website operators, such as Slevomat in the Czech

1 This article was written within the GAČR grant no. P408/14-27757S.

2 Department of Civil Law And Labour Law, Faculty of Law, Palacký University in Olomouc, Czech Republic. 
Republic ${ }^{3}$, or Groupon at the international level) and their practices which can be unknown territory to most consumers. The "Deal-of-the-day" websites (discount websites) are websites offering consumers a service, to buy discounted (often gift) certificates (coupons) which can be used at local or national companies. The principle is that a certain number of people must sign up for a given offer. After a certain number of people signs up, the deal becomes available to all. However if the given minimum of people "buying" the coupons is not met, no one gets the deal of the day. This way of selling goods and services reduces the risk for retailers, because they can sell the coupons as quantity discounts and use them as sales promotion tools at the same time. The discount website operator makes money by keeping approximately half of the amount which the consumer pays for the coupon. Yet still, there is no complex legal regulation of this young and rapidly growing business. Although the European Commission, with the Council's support, launched a process to review the consumer acquis, aimed at examining how consumer directives actually work in practice, to be followed by the adoption of any necessary measures, not much has been done in this area. The result of this rewiev was the new Directive 2011/83/EU of the European Parliament And Of The Council of 25 October 2011 on consumer rights, amending Council Directive 93/13/EEC and Directive 1999/44/EC of the European Parliament and of the Council and repealing Council Directive 85/577/EEC and Directive 97/7/EC of the European Parliament and of the Council.

One could argue that this field of discount website operators' practices is covered by the unfair trade practices provisions and unfair terms regulation, which may be true only at the first sight. When examining the issue in more depth, we realise that there are many potential threats for the consumers who are not always as protected by consumer law as they should be.

The "exclusivity" of the offers lies mainly in a time-limited offer (the offers usually last for several days). The consumer thus has a limited time to think the offer through - he/she is told that this offer is limited and won't come back any more. The consumer is also tempted by the "comparison" of the previous and new price, which shows directly how much money the consumer saves.

However, the number of discount website operators is reducing. According to some opinions the reason for this is the change in consumers' behaviour and complaints of unfair practices both from the website operators and the mecrhants. One percent of the discount offers can also be risky ${ }^{4}$ meaning that the consumer pays for the goods or services but doesn't get any.

3 TŮMA, O. Tomáš „Slevomat“ Čupr: Slevový server byl chladný kalkul. In: penize.cz [online]. 05.04.2011 [cit. 2013-12-15]. Accessed from http://www.penize.cz/slevy/199500tomas-slevomat-cupr-slevovy-server-byl-chladny-kalkul.

4 Čistka mezi slevovými portály - za rok jich skončilo přes sto. Ceskatelevize.cz [online]. 2. 8. 2011 [cit. 2013-12-16]. Accessed from: http://www.ceskatelevize.cz/ct24/ ekonomika/131811-cistka-mezi-slevovymi-portaly-za-rok-jich-skoncilo-pres-sto/. 


\section{Problematic aspects}

Collective buying and discount offers at the deal-of-the-day websites can give real benefits both to the consumers and merchants. On the other hand due to the fact that the discount website services are a relatively new industry, in many cases the specific legal handling is unclear and the discount website operators may violate several important aspects of consumer protection law.

The aim of this article is not to cover the issue of consumer protection as a whole, but rather concentrate on certain problematic aspects which cause problems in legal theory and practice and on which there is no sufficient Czech literature which would offer a complex legal solution of the following problems:

What is the character of the legal relationship of parties when concluding a contract through the discount portal? Is the discount website operator liable for the merchant's nonperformance or malperformance? How to address the problem of overstating the full price and suggested quality and quantity of goods and services offered at the discount websites? Is there any protection for a consumer when buying gift cards at the discount websites? Is the consumer protected when buying travel vouchers at the discount websites? What happens to the legal relationship if the mechant goes bankrupt? Is the consumer protection regulation applicable in all of these cases? If so, is it efficient?

\subsection{The nature of the legal relationship between the consumer, the dis- count website operator and the merchant}

The consumer buys vouchers at the discount website, operator's who are in a legal relationship with the merchant. The discount website operator receives the money from the consumer, keeps a certain amount as a provision and the outstanding amount is sent to the merchant. The consumer then asks the merchant to provide the service or goods offered.

The problem is the legal relationship between the consumer and these two other parties. There can be two types of discount website operators. The first one is a normal internet shop which sells discount vouchers and thus acts as a seller. The other (second) type is a web site which acts only as an intermediary between the consumer and the merchant. The discount website operator in this case declares that he offers his service purely on a basis of a mandate contract which in the end means that he is basically not liable for anything. This is conected to another problem mentioned in the following point - merchant's nonperformance or malperformance of the service/goods and insufficient quantity or poor quality (2.3).

The first example of a legal relationship should not cause any interpretional problems. The website operator acts as a seller himself, the legal relationship thus arises between him and the consumer which gives the consumer all rights stated 
by the law. Even if the website operator claims he is not the direct seller, the interpretation of the legal relationship comes from the actual situation - if he sells the goods/services (and for example issues ther invoices in his name), no matter what he claims he is the seller.

Concerning the other (second) type of relationship, the New Civil Code for the purposes of consumer protection defines ${ }^{5}$ the entepreteur not only as a person who independently carries out on his own account and responsibility trade or professional activity with the intent to do so consistently for profit, but also (for the purposes of consumer protection and for the purposes of $\$ 1963 \mathrm{CC}$ ) as any person who enters into a contract related to their commercial, industrial or similar activities, or in the exercise of his own profession, or any person acting for or on behalf of the entrepreneur.

\subsection{Overstating the real (full) price of the goods or services}

The discount website operator must make sure that the offers are clear, transparent and accurate. The operators should not engage in misleading or false conduct and should provide the consumer with precise information on the total price including possible fees and charges, perfect description of the goods or services offered and the discount given to the consumer at the discount website.

Still, one of the main problems is that the disount website operator (or the merchant himself) overstates the real (full) price of the goods or services offered at the discount website, making the discount seem larger than it really is. The consumer thus thinks he pays a lower price for goods or services which - if compared to other offers on the internet - is the same or even lower. Still, the merchant or the discount website claims that this is "the best deal of the day the consumer can get".

Private law does not usually give any limits to the price range of the goods and services offered by the merchants. The price is stated as a usual price, unless the parties agree upon something else or unless a special legal regulation states otherwise.

However, in this case the consumer may be protected under the legal regulation of the unfair commercial practices covered by the Act no. 634/1992 Coll., on Consumer Protection. As set by law, a commercial practice can be considered as unfair if it is contrary to the requirements of professional diligence and it materially distorts or is likely to materially distort economic behaviour with regard to the product for the average consumer whom it reaches or to whom it is addressed.

The conduct described above can be thus particularly taken as a misleading commercial practice because it contains false information and is therefore

5 Art. 420 of Act no. 89/2002 Coll., Civil Code. 
untruthful or in any way, including overall presentation, deceives or is likely to deceive the average consumer, even if the information is factually correct, in relation to one or more of the following elements, such as the existence or nature of the product, the main characteristics of the product, its availability, benefits, risks, execution, composition, accessories, delivery, fitness for purpose, usage, quantity, specification, geographical or commercial origin or the results to be expected from its use, or the results and material features of tests or checks carried out on the product. It further covers the misleading information on the extent of the trader's commitments, the motives for the commercial practice and the nature of the sales process, any statement or symbol in relation to direct or indirect sponsorship or approval of the trader or the product. Last but not least it covers the price or the manner in which the price is calculated, or the existence of a specific price advantage. This all may cause or is likely to cause the consumer to take a transactional decision that he/she would not have taken otherwise.

For such unfair practices the enterpreneur may be punished by a fine of up to 3000000 Czech Crowns.

\subsection{Discount website operator's liability for merchant's nonperformance or malperformance of the service/goods and suggested quantity and quality}

The consumers who bouht the discount vouchers often complain that it is merely impossible to book the service which they bought on the discount website. In addition, the merchant treat the discount voucher consumers different from their "normal" clients (smaller portions of food, dirty tables, cold rooms with a window view to the dirty courtyard etc. ${ }^{6}$ ).

The discount website operators claim to be mere marketing vendors that are irresponsible for the conduct of the corresponding merchant's services/goods. The website operators say that the merchant is the seller of the voucher and is thus solely responsible for redeeming any voucher the consumer purchases. The discount website operators usually say that they cannot ensure that merchants are able to fulfill the goods or services offered by vouchers in the quantity or quality suggested. This may again be considered as a misleading practice described above.

In addition it is contrary to the basic legal regulation of performace without defects described in the Civil Code. According to this regulation the entrepreneur is obliged to perform without defects ${ }^{7}$ with properties negotiated in the

6 The consumers even established a specialised website where all deceited consumers can write their experience and warn the others from buying this discount. antislevy.cz. Some of the discount website operators guarantee return of consumers'money if they are not satisfied with the goods or services they bought at their websites. This guarantee is however limited. See Garance spokojenosti a reklamace. Slevomat.cz [online]. [cit. 2013-12-16]. Accessed from: http://www.slevomat.cz/garance.

7 Art. 1914 of Act no. 89/2002 Coll., Civil Code. 
contract or usual so that the goods or services can be used according to the subject matter of the contract. If fulfilled with defects ${ }^{8}$, the recipient (creditor-consumer) gets additional rights arising from this malperformace.

\subsection{Gift cards}

The consumer in fact prepays goods or services which $S /$ he intends to get or use, the vouchers are valid for a certain period of time at a specific places. The question at stake is however what happens after the date of a voucher expires without the consumer being able to use the remaining value that $\mathrm{s} / \mathrm{he}$ paid for. Will the discount website operator or the merchant her/himself refund the value of the expired vouchers?

This is generally a problem of gift cards which are not regulated by Czech law (unlike e.g. in the USA where the law defines a gift card as a prepaid good for a predetermined value, and can be redeemed for goods or services at a specified business. The gift card must have an expiration date of a certain length, not less than six months). The Czech courts already dealt with a case in which the entrepreneur offered gift certificates that shall become void without compensation after one year. The unused voucher could not be returned (reimbursed) and the consumer ended with no compensation nor could they redeem the voucher for cash. According to the court this contractual term is however not unfair. Concenring the transparency of such a contractual term, the entrepreneur stated these conditions clearly and unambigiuasly. The consumer thus could not have any reasonable doubt, that if $s /$ he does not use the coupon for purchasing goods within a specified time, $\mathrm{s} / \mathrm{he}$ will be no longer entitled to a discount, nor will s/he get a refund for the price that $\mathrm{s} / \mathrm{he}$ paid for the coupon. With the gift certificate the consumer is free to dispose, in particular s/he can pass (donate) it to a third party, which is the main purpose of the gift certificates. The entrepreneur thus fullfills his obligation simply by creating and ensuring, that the conditions for the buyer to donate the asset (voucher) to a third party exist. The performace of the entrepreneur is thus fulfilled even in cases that the coupon is not used to get the ordered goods. The court also compared the situation to the purchase of a season ticket (e.g. ski pass) where the consumer doesn't get the money back if $s /$ he doesn't use the tickets fully. No one can be forced to consume the purchased thing; a fixed time period for the use of a coupon is not likely to cause the consumer harm. The period of one year through which the consumer can us the right to use a coupon is proportionate to the possibilities of a consumer

8 In general the debtor is obliged to perform in medium quality, unless the parties agree upon special quality; the law gives examples of performace with defect - such as if the subject of performance does not have given or negotiated properties, the creditor does not tell the consumer about the defects of the goods or services, tells the consumer explicitely that the goods or services have no defect or if s/he sells goods which do not belong to him. If an entrepreneur claims that there is a limit in the the scope of his duties for malperformance, that statement shall be considered ineffective. 
or another person to whom the coupon is submitted, to make a judicious decision on the purchase. The coupons are in such denominations that can be easily used and exhausted. In other words, the value of the coupons corresponds to the length of the period, which is designed for the option to use a coupon to buy the selected goods. Although a contractual term stating that "unless a gift certificate (coupon) is used within one year of purchase, it becomes void without compensation" is advantageous only for the entrepreneurs, still it can not be concluded that it represent an unreasonable condition (abusive clause) for the consumer. The consumer buys a gift certificate (coupon), knowing that its validity is limited in time and render the arrangement that the "unused" coupon is provided with a "replacement". This disadvantage is balanced by the fact that the entrepreneur is obliged to accept the counpon not only from the consumers who bought them, but also by any other person who brings the coupon to their premises. In addidtion, the consumer her/himself has the possibility to "limit" the advantage of the entrepreneur by simply purchasing the goods or services within an agreed time.

In this case the Court set the criteria for assessing the unfairness of a contractual term for gift vouchers. It took into account various aspects of parties'autonomy of will, in addition it also pointed out the principle of pacta sunt servanda. ${ }^{9}$

\subsection{Travel vouchers}

Consumers who want to buy a travel package are protected by the provisions of the Council Directive 90/314/EEC of 13 June 1990 on package travel, package holidays and package tours. The directive offers protection to consumers who should have the benefit of the protection irrespective of whether $\mathrm{s} / \mathrm{he}$ is a direct contracting party, a transferee or a member of a group on whose behalf another person has concluded a contract in respect of a package. According to the Court of Justice of EU the term package must be interpreted so as to include holidays organised by travel agents, at the request of and in accordance with the specifications of a consumer or limited group of consumers. According to the definition of package given in Article 2(1) of the directive, which is designed amongst other things to protect consumers who buy package holidays, it is enough if, first, the combination of tourist services sold by a travel agency at an inclusive price includes two of the three services referred to in that paragraph and, second, that service covers a period of more than 24 hours or includes overnight accommodation. There is nothing in that definition to suggest that holidays organised at the request of and in accordance with the specifications of a consumer or a defined group of consumers cannot be regarded as package holidays within the meaning of the Directive. That interpretation is reinforced by the directive, which provides that among the elements to be included in a contract covered by the directive are special requirements

9 Judgement of the Supreme Court of the Czech Republic of 30. 3. 2010, no. 33 Cdo $1956 / 2007$. 
which the consumer has communicated to the organiser or retailer when making the booking, and which both have accepted. As the definition of package referred to in Article 2(1) of Directive 90/314 on package travel, package holidays and package tours includes holidays organised in accordance with the consumer's specifications, the term pre-arranged combination used in that provision necessarily covers cases where the combination of tourist services is the result of the wishes expressed by the consumer up to the moment when the parties reach an agreement and conclude the contract. The term pre-arranged combination used in Article 2(1) of Directive 90/314 must be interpreted so as include combinations of tourist services put together at the time when the contract is concluded between the travel agency and the consumer. ${ }^{10}$

The organiser of the package and/or the retailer are obliged to ensure that in descriptive matters relating to packages which they respectively organise and sell, the information which is given is not misleading and brochures made available to consumers contain information that is comprehensible and accurate. The organizer and/or retailer party to the contract should be liable to the consumer for the proper performance of the obligations arising from the consumer contract. The organiser and/or retailer should be also liable for the damage resulting from the consumer for the failure to perform or improper performance of the contract unless the defects in the performance of the contract are attributable neither to any fault of theirs nor to that of another supplier of services. The liability of the organiser and/or retailer for failure to perform or improper performance of the services involved in the travel package should be limited in accordance with the international conventions governing such services, in particular the Warsaw Convention of 1929 in International Carriage by Air, the Berne Convention of 1961 on Carriage by Rail, the Athens Convention of 1974 on Carriage by Sea and the Paris Convention of 1962 on the Liability of Hotel-keepers.

The liability here covers not only material damage, it covers also the nonmaterial damage. As the Court of Justice of EU ruled, that the Directive, and in particular Article 5 thereof, is designed to offer protection to consumers and, in connection with tourist holidays, compensation for non-material damage arising from the loss of enjoyment of the holiday is of particular importance to consumers. It is in light of those considerations that Article 5 of the Directive is to be interpreted. Although the first subparagraph of Article 5(2) merely refers in a general manner to the concept of damage, the fact that the fourth subparagraph of Article 5(2) provides that Member States may, in the matter of damage other than personal injury, allow compensation to be limited under the contract provided that such limitation is not unreasonable, means that the Directive implicitly recognises the existence

10 Case C-400/00. Club-Tour, Viagens e Turismo SA v Alberto Carlos Lobo Gonçalves Garrido, and Club Med Viagens $L d^{a}$. [2002] ECR I-04051. 
of a right to compensation for damage other than personal injury, including nonmaterial damage. ${ }^{11}$

Although the consumer buys a travel voucher from the discount website operator who acts on the basis of a mandate contract, the consumer should be protected by these provisions which are implemented in the new Civil Code.

\subsection{Merchant possible bankruptcy or termination of business activity}

The prepaid vouchers which the consumer buys are valid for a certain period of time. The problem is what happens if the consumer buys a voucher and the merchant goes out of business before the consumer uses the voucher. The question is who is responsible for the unreceived goods or services - the discount website operator who sold the voucher or the merchant her/himself? This is where the question of the mandate contract comes at stake. At the moment, some of the discount website operators offer a special insurance for the vouchers in case the mechant goes bankrupt.

There are several ways of terminating the business activity - it depends on whether an entrepreneur is a natural person acting as an entrepreneur or wthether $\mathrm{s} /$ he runs the business as a legal person. A natural person-enterpreneur can submitt a request for cancellation of the trade license to the Licensing Office. If s/he meets all the requirements, the Licensing Office issues a decision on the cancellation of the trade license within 30 days. The natural person-enterpreneur must report the termination of the business at the Health Insurance Company, Social Security Administration and Financial Office. However s/he has no direct obligation to let all her/his creditors know individually. Nevertheless, a natural person acting as en entrepreneur is liable for their detbs even after the termination of the business. This means that s/he must pay all the detbs even after the termination of the business and if $\mathrm{s} / \mathrm{he}$ does not fullfill the obligation, the creditors can ask the court to take possession of the property of the entrepreneur, to sell it and to use the proceeds to pay the debts.

Legal persons, typically limited companies, have a limited liability for the debts caused by the company. Nevertheless, a person who becomes a member of an elected body must carry out her/his performace with the necessary loyalty and necessary knowledge and care. A person acts negligently, if she/he is not capable of professional care, although she/he knew when accepting this position or found out during the performace, and does not draw any consequences for her/himself. The court may decide, upon a request of the insolvency administrator or creditors, that a member or a former member of the statutory body is responsible for the fulfillment of its obligations. The court is allowed to declare this under two conditions: it was decided that a business corporation is insolvent, and the member or former member of the statutory body of the corpora-

11 Case C-168/00 Simone Leitner v TUI Deutschland GmbH \& Co. KG.[2002] ECR I-02631.

(C) Palacký University Olomouc, Czech Republic, 2013.

ISSN 1213-8770 (print), ISSN: 2464-6601 (online). 
tion knew or should have known, that the corporation may go bankrupt, and contrary to the due diligence they haven't done anything to avert the bankruptcy. The court may even give a ruling that the members of the company bodies must give out all benefits obtained from the company, if they knew or should have known, that the corporation may go bankrupt, and contrary to the due diligence haven't done anything about it.

\section{Code of Conduct}

In order to make the business of discount website operators more transparent, some of them join and sign up to certain codes of conduct which are developed to demonstrate the industry's commitment to high ethical standards and good practice. The main aim of these codes of conduct is to increase consumer confidence in dealing with group buying platforms, ensure that consumers have access to product and service information they need to make informed choices (this includes information on the total price of the goods or services including all fees and charges, the description of the goods or services and the discount itself), to promote compliance within the industry with relevant laws and promote fair, honest, ethical best practice within the group buying industry. The consumers shall always fully understand the offer before accepting it, the discount website operators must ensure that appropriate policies and procedures are in place and all commercial electronic messages comply with relevant legislation.

Concerning the pricing, the discount website operators must ensure that the original price of the goods or services outlined in the offer is the actual price that the consumer would pay for the identical goods or services if they purchased the goods or services directly from the merchant.

Concerning the problems with quantity of vouchers offered at discount websites, it is first of all the entrepreneurs who must undertake a capacity calculation. The operators shall then take all reasonable steps to ensure they do not knowingly sell vouchers for a quantity of product which exceeds the number available from the merchant or of a service that cannot be fulfilled by the merchant within the timeframe that the offer is valid. The entrepreneur himself must undertake a capacity calculation. ${ }^{12}$

\section{Final word}

The discount website service is a relatively new industry in the Czech Republic. Most of the consumers are not aware of the fact that they have certain rights, in some cases it is very difficult to say under which legal regulation the legal rela-

12 See Australian Group Buying Code of Practice 2013. Adma.cz [online]. [cit.2013-12-16]. Accessed from: http://www.adma.com.au/assets/Uploads/Comply-Documents/GroupBuyingCode.pdf. 
tionship between the consumer and the entrepreneur runs (whether the operator acts as a seller or intermediary under the mandate contract).

Unfortunately there is not sufficient Czech literature in this field; there are only a few popular articles which touch on this topic. Due to the fact that this is a relatively common and known industry abroad, there are foreign articles which already highlight consumer protection within this area. These articles however come from a different legal environment; most of them are of American origin which is not applicable to the Czech legal regulation. There is almost no Czech case law in this area. If there is a precedent, it deals with the unfair terms in general, not in connection with the discount websites. This issue however will come more apparent as the consumers realise their rights and start to sue the operators for not performing what they promised to. It will be thus the judges who will start the interpretation of this relationship and give possible instructions how to solve these disputes. 